\title{
Efficacy of Some Bacterial Biocontrol Agents as Seed Treatment against Root Knot Nematode, Meloidogyne incognita on Tomato
}

\author{
Karter Nyodu* and Debanand Das \\ Department of Nematology, Assam Agricultural University, Jorhat (Assam) 785 013, India \\ *Corresponding author
}

\section{Keywords}

Bacterial biocontrol agents, Seed treatment, Root knot nematode

\section{Article Info}

Accepted:

10 August 2020

Available Online:

10 September 2020

\section{A B S T R A C T}

Pot experiment was conducted to evaluate the efficacy of two formulations (talc formulation and vermi formulation) of four bacterial nematode biocontrol agents viz., Bacillus subtilis, Bacillus pumilus, Bacillus megaterium and Pseudomonus flourescens as seed treatment against root knot nematode, Meloidogyne incognita on tomato. All the bioagents were tries at 10 and $20 \mathrm{~g} /$ $\mathrm{kg}$ of seed. The experiment was terminated at 60 days after sowing the seed. The results revealed that all the treatments significantly increased the plant growth parameters and reduced the nematode multiplication over untreated control. However, maximum plant growth parameters and minimum galls per root system, eggmasses per root system, eggs per egg masses and final nematode population was recorded when seeds of tomato (var. Pusa Ruby) was treated with talc formulation of Pseudomonus flourescens @ $20 \mathrm{~g} / \mathrm{kg}$ followed by seed treatment with vermi formulation of Bacillus subtilis@20g/kg of seed.

\section{Introduction}

In recent years, management of plant parasitic nematodes using biocontrol agents (fungal as well as bacterial) is gaining importance in the light of increased awareness of environmental and human health hazards associated with nematicidal chemicals application. Biological control promises to be one of these alternatives. Biological agents are environment-friendly, hence cause no side effect, they are affordable compared to agrochemicals (pesticides, insecticides, nematicides) and easy to use. Among the biological control agents that have been assessed against nematodes are antagonistic bacteria, nematophgous fungi and yeasts (Das and Borgohain, 2018; Jayakumar, 2019). A good number of bacterial biocontrol agents have been identified for their nematicidal action on root knot nematodes and becomes promising source of biopesticides. The present investigation aims to evaluate the efficacy of few bacterial biocontrol agents as 
seed treatment against root knot nematode, which is responsible for 27.21 per cent annual yield loss of tomato.

\section{Materials and Methods}

Pot experiment was laid out at 4CRD in the Net House of Department of Nematology, Assam Agricultural University, Jorhat with thirteen treatments, viz., $\mathrm{T}_{1}$ : Seed treatment with Bacillus subtilis $\left(1 \times 10^{9} \mathrm{cfu} / \mathrm{gm}\right.$ of talc formulation) @ $10 \mathrm{gm} / \mathrm{kg}$ of seed; $\mathrm{T}_{2}$ : Seed treatment with B. subtilis $\left(1 \times 10^{9} \mathrm{cfu} / \mathrm{gm}\right.$ of talc formulation) @ $20 \mathrm{gm} / \mathrm{kg}$ of seed; $\mathrm{T}_{3}$ : Seed treatment with $B$. subtilis $\left(1 \times 10^{9} \mathrm{cfu} / \mathrm{gm}\right.$ of vermi formulation) @ $10 \mathrm{gm} / \mathrm{kg}$ of seed; $\mathrm{T}_{4}$ : Seed treatment with B. subtilis $\left(1 \times 10^{9} \mathrm{cfu} / \mathrm{gm}\right.$ of vermi formulation @ $20 \mathrm{gm} / \mathrm{kg}$ of seed; $\mathrm{T}_{5}$ : Seed treatment with $B$. pumilus $\left(1 \times 10^{9} \mathrm{cfu} / \mathrm{gm}\right.$ of talc formulation) @ $10 \mathrm{gm} / \mathrm{kg}$ of seed; $\mathrm{T}_{6}$ : Seed treatment with B. pumilus $\left(1 \times 10^{9} \mathrm{cfu} / \mathrm{gm}\right.$ of talc formulation) @ $20 \mathrm{gm} / \mathrm{kg}$ of seed; $\mathrm{T}_{7}$ : Seed treatment with $B$. megaterium $\left(1 \times 10^{9} \mathrm{cfu} / \mathrm{gm}\right.$ of talc formulation) @ $10 \mathrm{gm} / \mathrm{kg}$ of seed; $\mathrm{T}_{8}$ : Seed treatment with $B$. megaterium $\left(1 \times 10^{9} \mathrm{cfu} / \mathrm{gm}\right.$ of talc formulation)@20gm $/ \mathrm{kg}$ of seed; $\mathrm{T}_{9}$ : Seed treatment with $B$. megaterium $\left(1 \times 10^{9} \mathrm{cfu} / \mathrm{gm}\right.$ of vermi formulation) @ $10 \mathrm{gm} / \mathrm{kg}$ of seed; $\mathrm{T}_{10}$ : Seed treatment with $B$. megaterium $\left(1 \times 10^{9} \mathrm{cfu} / \mathrm{gm}\right.$ of vermi formulation) @ $20 \mathrm{gm} / \mathrm{kg}$ of seed; $\mathrm{T}_{11}$ : Seed treatment with Pseudomonas fluorescence $\left(1 \times 10^{9} \mathrm{cfu} / \mathrm{gm}\right.$ of talc formulation) @ $10 \mathrm{gm} / \mathrm{kg}$ of seed; $\mathrm{T}_{12}$ : Seed treatment with $P$. fluorescence $\left(1 \times 10^{9} \mathrm{cfu} / \mathrm{gm}\right.$ of talc formulation) @ $20 \mathrm{gm} / \mathrm{kg}$ of seed and $\mathrm{T}_{13}$ : Untreated control. Seeds of susceptible tomato variety (Pusa Ruby) were pre soaked in water for 12 hours, treated with biocontrol agents with calculated amount and then incubated at $25-30^{\circ} \mathrm{C}$ for 48 hours. Treated seeds were raised in sterilized pot mixture of sand, field soil and cowdung at $1: 2: 1$ in $1 \mathrm{~kg}$ earthen pots. Seedlings were thinned to keep one healthy seedling per pot at 3 leaf stage. Second stage juveniles of root knot nematode Meloidogyne incognita were inoculated around the root zone of tomato seedlings at $1 \mathrm{~J}_{2} / 1 \mathrm{~g}$ of soil. Seedlings were maintained following package of practices. The experiment was terminated at 60 days after sowing the seeds and observations on plant height, root length, fresh and dry shoot weight, fresh and dry root weight, number of galls per root system; numbers of egg masses per root system and final soil nematode population were recorded.

\section{Results and Discussion}

Results revealed that all the treatments significantly increased the plant growth parameters and reduced the infestation of root knot nematodes in tomato. However, maximum plant growth parameters and minimum number of galls, eggmass per root system, final soil nematode population were recorded when tomato seeds (var. Pusa Ruby) were treated with Pseudomonas fluorescens @ 20g/kg seed $\left(\mathrm{T}_{12}\right)$, followed by seed treatment with Bacillus subtilis (vermi formulation) @ $20 \mathrm{~g} / \mathrm{kg}$ seed $\left(\mathrm{T}_{4}\right)$; whereas, minimum was recorded in untreated control ( $\mathrm{T}_{13}$ ) (Table 1).

Maximum plant height $(39.23 \mathrm{~cm})$, root length $(16.29 \mathrm{~cm})$, fresh shoot and root weight $(15.59 \mathrm{~g}$ and $9.70 \mathrm{~g})$, dry shoot and root weight (5.88g and $4.81 \mathrm{~g}$ ) were recorded when seeds were treated with Pseudomonas fluorescens (a 20g/kg seed. All plant growth parameters were minimum at control, where only $M$. incognita were inoculated. Minimum galls per root system (12.00), eggs per egg mass (16.25) and final nematode population per $200 \mathrm{cc}$ of soil (110.25) were recoded when seeds were treated with Pseudomonas fluorescens@20 g/kg seed $\left(\mathrm{T}_{12}\right)$, followed by seed treatment with Bacillus subtilis (vermi formulation) @ $20 \mathrm{~g} / \mathrm{kg}$ seed $\left(\mathrm{T}_{4}\right)$; whereas, minimum was recorded in untreated control $\left(\mathrm{T}_{13}\right)$ (Table 2). The result of the present 
investigation clearly showed that bacterial infestation of root knot nematode, $M$. bio-agents can effectively manage the incognita in tomato.

Table.1 Effectiveness of bacterial bioagents as seed treatment on plant growth parameters of tomato (var.- Pusa Ruby)

\begin{tabular}{|l|c|c|c|c|c|c|}
\hline Treatment & $\begin{array}{c}\text { Plant } \\
\text { Height }\end{array}$ & $\begin{array}{c}\text { Fresh Shoot } \\
\text { weight }\end{array}$ & $\begin{array}{c}\text { Dry shoot } \\
\text { weight }\end{array}$ & $\begin{array}{c}\text { Root } \\
\text { Length }\end{array}$ & $\begin{array}{c}\text { Fresh Root } \\
\text { weight }\end{array}$ & $\begin{array}{c}\text { Dry root } \\
\text { weight }\end{array}$ \\
\hline T1 & 31.40 & 10.90 & 3.96 & 11.55 & 5.29 & 2.33 \\
\hline T2 & 31.78 & 10.95 & 3.73 & 13.29 & 6.17 & 2.94 \\
\hline T3 & 32.48 & 12.93 & 3.74 & 12.57 & 6.01 & 2.65 \\
\hline T4 & 37.13 & 14.69 & 4.23 & 14.51 & 7.90 & 3.83 \\
\hline T5 & 29.90 & 9.54 & 2.67 & 10.77 & 5.15 & 1.99 \\
\hline T6 & 33.33 & 11.38 & 3.27 & 11.99 & 5.62 & 2.42 \\
\hline T7 & 29.98 & 9.03 & 2.59 & 10.96 & 5.17 & 1.79 \\
\hline T8 & 29.10 & 8.47 & 2.53 & 11.30 & 6.90 & 3.32 \\
\hline T9 & 31.20 & 9.085 & 2.41 & 11.56 & 5.80 & 1.16 \\
\hline T10 & 31.73 & 10.44 & 2.92 & 11.63 & 5.61 & 1.34 \\
\hline T11 & 33.18 & 12.36 & 3.24 & 12.25 & 6.62 & 1.88 \\
\hline T12 & 39.23 & 15.59 & 5.88 & 16.29 & 9.70 & 4.81 \\
\hline T13 & 21.63 & 7.11 & 1.49 & 9.22 & 4.65 & 1.13 \\
\hline SEd & 3.37 & 1.32 & 0.7 & 0.88 & 0.89 & 0.56 \\
\hline CD(0.05) & 5.65 & 2.21 & 1.18 & 1.48 & 1.49 & 0.93 \\
\hline
\end{tabular}

Table.2 Effectiveness of bacterial bioagents as seed treatment on infestation of root knot nematode, Meloidogyne incognita on tomato

\begin{tabular}{|l|c|c|c|}
\hline Treatment & Gall/root system & $\begin{array}{c}\text { Egg mass/root } \\
\text { system }\end{array}$ & $\begin{array}{c}\text { Final nematode population } \\
\text { (200 cc of soil) }\end{array}$ \\
\hline T1 & 34.0 & 36.50 & 145.25 \\
\hline T2 & 20.50 & 26.00 & 138.25 \\
\hline T3 & 33.00 & 31.50 & 149.00 \\
\hline T4 & 19.00 & 21.00 & 131.00 \\
\hline T5 & 34.50 & 34.50 & 162.25 \\
\hline T6 & 29.25 & 27.50 & 155.50 \\
\hline T7 & 36.50 & 36.50 & 168.25 \\
\hline T8 & 35.00 & 30.00 & 143.00 \\
\hline T9 & 39.00 & 31.50 & 164.50 \\
\hline T10 & 32.50 & 25.00 & 147.00 \\
\hline T12 & 29.50 & 20.50 & 130.50 \\
\hline T13 & 12.00 & 16.25 & 110.25 \\
\hline SEd & 50.50 & 41.00 & 231.25 \\
\hline CD(0.05) & 3.16 & 2.89 & 10.65 \\
\hline
\end{tabular}


The present findings are in the line of findings reported by Verma et al., (1998), Ali et al., (2002), Hashem and Abo-Elyousr (2011) and Roy et al., (2015). Verma et al., (1998) reported that application of Pseudomonas fluorescens @ $10 \mathrm{~g} / \mathrm{kg}$ seed was effective in reducing the menace of root-knot nematode, Meloidogyne incognita in tomato. Hashem and Abo-Elyousr (2011) conducted an experiment to evaluate the nematicidal activity of Pseudomonas fluorescens, Paecilomyces lilacinus, Pichia guilliermondii and Calothrix parietina against root-knot nematode (Meloidogyne incognita) on tomato. Tomato seeds were immersed in the biocontrol agent suspensions, which contained separately $10^{8}$ cell $\mathrm{ml}^{-1}$ of $P$. fluorescens, $10^{5}$

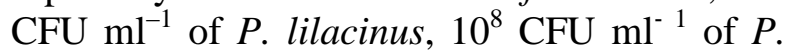
guilliermondii and $10^{5}$ cell $\mathrm{ml}^{-1}$ of $C$. Parietina. Sterile distilled water (DW) was used as control. Results revealed that all treatments significantly reduced the population of $M$. incognita and root galling on tomato along with increased percentage of germination and vigor index (VI) except, C. parietina, which has no significant difference from the control. Among all the treatments the most vigorous root system was obtained in the treatment with $P$. fluorescens. Sonkar et al., (2018) observed that $P$. fluorescens was able to reduce nematode parameters at different concentration when applied either as seedling root dip treatment or soil drench around tomato. Siddiqui and Shaukat (2002) revealed that these rhizobacteria have the ability to induce systemic resistance against root knot nematode, which may paly role in the present study.

\section{References}

Ali, N. I., Siddiqui, I. A., Shaukat, S.S. and Zaki, M.J. (2002). Nematicidal activity of some strains of Pseudomonas spp. Soil Biology and Biochemistry, 34:1051-1058.
Das, Debanand and Borgohain, Nibedita (2018). Biological approach for management of nematodes in banana. Ann. Pl. Protec. Sci. 26:374-377

Hashem, M. and Abo-Elyousr, K.A. (2011). Management of the root-knot nematode Meloidogyne incognita on tomato with combinations of different biocontrol organisms. Crop Protection. 30: 285-292.

Jayakumar, J. (2019). An evaluation of biocontrol agents for management of sugarcane nematodes under field condition. Ann. Pl. Protec. Sci.27: 261263

Roy, S., Rathod, A. and Pramanik, A. (2015). Bioefficacy of Bacillus subtilis against root-knot nematode Meloidogyne incognita (Kofoid and White) Chitwood in tomato. Journal of Applied and Natural Science., 7: 1012-1015.

Siddharth Shankar Sonkar, Jayant Bhatt, Jhumishree Meher and Punam Kashyap. (2018). Bio-efficacy of Pseudomonas fluorescens against the Root-Knot Nematode (Meloidogyne incognita) in Tomato Plant. Int.J.Curr.Microbiol.App.Sci. $\quad 7(11)$ : 1692- 1699.

Siddiqui, IA. And Shaukat, SS. (2002). Rhizobacteria-mediated induction of systemic resistance (ISR) in tomato against Meloidogyne javanica. Journal of Phytopathology, 150, 469-473

Verma, K.K., Gupta, D.C., Paruthi, I.J., Dhawan, S.C. and Kaushal, K.K.(1998). Preliminary trial on the efficacy of Pseudomonas fluroscens as seed treatment against Meloidogyne incognita in tomato. In Proceeding of National Symposium on Rational Approaches in Nematode Management for Sustainable Agriculture.pp.79-81.

\section{How to cite this article:}

Karter Nyodu and Debanand Das. 2020. Efficacy of Some Bacterial Biocontrol Agents as Seed Treatment against Root Knot Nematode, Meloidogyne incognita on Tomato. Int.J.Curr.Microbiol.App.Sci. 9(09): 1043-1046. doi: https://doi.org/10.20546/ijcmas.2020.909.129 